\title{
Measuring the Unmeasurable? Production \& Certification of Halal Goods and Services
}

\author{
Aisalkyn Botoeva \\ Visiting Fellow, Institute for European, Russian and Eurasian Studies, The \\ George Washington University, Washington, DC, USA \\ aisalkyn.botoeva@gmail.com
}

\begin{abstract}
Attending to the rise of halal economy and particularly halal certification initiatives in the region and globally, this paper asks why and how third-party certifiers would gain credibility and authority, and what does authority have to do with the work of entrepreneurs in the sector. Drawing on fieldwork conducted between 2012 and 2015, and interviews with entrepreneurs and a private halal certification agency in Kyrgyzstan as well as their accreditors in Kazakhstan, I pay close attention to the collective meaning-making deliberations that revolve around questions of what makes goods and services halal and also what makes one a 'good Muslim'. Certifiers and entrepreneurs come to form what I call a valuation circuit. In these circuits, they construct shared understandings of ethnical and behavioral norms for market actors, create and reinforce binaries around halal and haram, and rely on transnational network of religious authority as they attempt to valuate and measure compliance to halal standards.
\end{abstract}

\section{Keywords}

halal - certification - Islam - Central Asia - economic sociology - moral markets

Starting in the early- to mid-20oos, the major cities of Bishkek and Osh in Kyrgyzstan and Astana and Almaty in Kazakhstan have boasted a wide range of businesses that are advertised as Islamic, Shariah-compliant or halal. These businesses range from large banks to microfinance and insurance companies (see Imam and Kpodar 2010), from Muslim daycare and halal food producers, 
to wholesale and retail traders of goods. A large subset of these companies, particularly food producers and those in the hospitality industry, has been particularly concerned with questions of what constitutes halal. According to the owners and managers of such businesses, the definition of halal standards cannot be taken for granted. At the time of my fieldwork between 2012 and 2015, both producers and consumers of halal goods and services voiced concerns over the ambiguity around what halal means and whether some entrepreneurs might be deceptive and offer something that was actually haram. Many entrepreneurs expressed doubt around their own compliance as well, frequently admitting, 'I'm not sure if my business is $100 \%$ halal.'

Against the backdrop of an ever-expanding 'halal' niche in the market, private halal certifiers emerged in collaboration with the muftiates in both countries and have quickly gained traction in the market. As of summer 2015, there were approximately 200 small to large businesses in Kyrgyzstan and 6oo small to large businesses in Kazakhstan that received halal certification from their country's respective agencies. Moreover, halal certifiers in Kazakhstan boasted that halal-compliant producers constituted 35\% of the country's GNP in 2014. The ubiquity of conversations about certification, particularly among the subset of entrepreneurs who mostly produce food products labeled 'halal', but also among entrepreneurs in the service sector running guest houses and Muslim daycare centers, prompts a question: Why would third-party halal certifiers gain credibility, and how do they build their authority in the eyes of entrepreneurs and other market actors? This question is at the core of the puzzling dissonance between the desire of so many to 'go halal' on the one hand, and the fuzziness of the requirements for processes and procedures that lead to 'real halal' commodity or service on the other hand (see also van Waarden and van Dalen 2011, 2013).

While the dissonance is informed by particular historical experiences of Muslims in the region who were isolated from the broader Muslim world for seven decades under the Soviet regime, it is also a reflection of the broader socio-cultural and political processes of how religious tenets are interpreted, debated and contended by the pious themselves. As Khalid notes, like many others, 'Islam ... is never a simple given, an agreed-upon set of rules or ideas. Rather, it contains infinite possibilities, and it goes where debate and contention among Muslims take it' (Khalid 2007: 161). In the past two decades, scholars of Central Asia have actively examined the 'struggles through which local actors themselves attempt to define what constitutes true Islam and a good Muslim' (Rasanayagam 2006). Among other reflections of piety, researchers have examined the construction of mosques with local community fundraising (Rashid 1994), the proliferation of Muslim charity boxes in grocery and 
other retail outlets, and increasing pilgrimages to Mekka, as well as veiling (Louw 2007, 2013; McBrien 2008, 2009; Privratsky 2001). Scholars often note the competing nature of the social dynamic, and how adherents of different streams and movements of Islam in the region grapple with notions of 'who is the right Muslim' and which repertoires of piety are compatible with local traditions (Louw 2013; McBrien \& Pelkmans 2008). The state leaders and government authorities have also fueled these debates and contributed to the discord, by promoting essentialist views of 'traditional Islam' (Bissenova 2017; compare Roy 2004).

I build on the foundation of these studies, but shift my attention from spaces and practices that are marked as 'religious' (e.g. medressah, mosques, veiling) to those that are seen as 'economic'. In doing so, I draw insight from economic sociology and explore how collective understandings of what is 'halal' and what is 'Islamic' are produced and reinforced in the market. In this sense, the Islamic business field is quite similar to other markets when they are perceived as being marked by risk and uncertainty, including the market for financial products (Mackenzie 2003; Sinclair 2014), antique commodities (Bogdanova 2013), and even labor markets (Gerlach 2013). When the value and the 'actual' quality of goods (or services) are invisible or opaque, entrepreneurs may profit from asymmetries of information (Beckert 2013; Beckert and Musselin 2013). The common consensus among studies of such uncertainty within economic sociology is that market actors require 'judgment devices' to make evaluations and judgments about the quality and worth of commodities. These devices can range from guidebooks and reviews (Dewally and Ederington 2006; Karpik 2010), to the advice of neutral third-party experts and authorities. For example, to decide what makes antique furniture authentic and valuable, people often listen to the authority of antique specialists and auction guides. Similarly, the halal sectors generally lack clear norms and standards for the quality of halal goods and services, as well as the sufficient means of measuring and monitoring compliance of commodities labeled as halal (van Waarden \& van Dalen 2013). Certification schemes and international standards, however voluntary their adoption, also serve as judgment devices (compare Masters and Sanogo 2002; Potoski and Prakash 2004).

This means in addition to the social uncertainties about the authenticity of an individual's or community's faith and true Muslimness faced by Muslims in Central Asia (Pelkmans 2013), entrepreneurs and other market actors in the region (and elsewhere) face uncertainty in ascertaining and communicating the qualities that makes goods and services permissible to Muslims. The halal economy revolves around how multiple actors, including entrepreneurs and certifiers, as well as investors and customers, resolve both the uncertainties 
of identity and uncertainties around qualities and value of products through activities, procedures and mechanisms in the market. I argue that halal markets broadly, but particularly halal certification process involves a series of protracted meaning-making deliberations and new courses of action to be undertaken by entrepreneurs and others involved in the market. It is through the deliberate search and enactment of shared understandings of what halal as well as 'good Islam' and 'good Muslims' mean, that these actors demarcate a new space of morality in the broader economy.

In the subsequent sections, I first discuss narratives of pious Muslim entrepreneurs concerning their doubts as to what makes one's goods and services halal, and their understanding of how to best practice halal in their everyday business lives and routines. From entrepreneurs' accounts, I then turn to certification agencies, which play a crucial role in promoting the idea of measuring the unmeasurable, and attributing value to halal goods and services. I demonstrate how certifiers gain authority through several key activities that include constructing collective understandings of what is halal and Islamic, localizing the meaning of halal, and creating binaries around halal and haram; finally, I also show how and when they rely on a transnational network of religious authority. All of this work is done in what I call 'valuation circuits', through which the authority of local halal certifiers takes on both local and global dimensions.

\section{Entrepreneurs' Accounts}

The question of what is the 'right Islam' is salient in Central Asia as elsewhere. Local Muslims of different backgrounds engage in the debate in various ways. What concerns them all, however, is how to balance religious and ethical guidelines with a certain degree of pragmatism. Economic actors in the various segments of the halal or Islamic economy want to both reinforce their spiritual aspirations and generate economic returns. Most of the entrepreneurs I interviewed reiterated a connection between piety, profit-making activities and the ideas of cultivating a better self and of building better societies.

Bairam, the owner of a halal confectionary shop with fifty employees in Osh opened his company with the help of his close Tajik friend who had experience in the industry. When I asked Bairam how he went about deciding on the company's specialization, he began his account with a discussion of how capitalist management and Islamic principles match each other well:

First of all, I do the namaz [prayer] five times a day, and I wanted my business to be clean as well.... My training was in management. I find that 
modern managerial principles actually overlap with Islamic tenets quite a bit. For example, the principles for good managers state that they need to consult with their workers; they need to make decisions democratically. But the hadiths in the Quran say similar things! They also instruct us to treat workers well, to pay them before their forehead sweat dries off [Kyr. mangdai teri kurgaganga cheiyn]. It's considered a form of sadaqa [benefaction, good deed] if you treat your workers respectfully and keep them content. ${ }^{1}$

Bairam regularly pointed to his workers, who were on the other side of a glass wall on one side of his office. He evoked some of the institutional knowledge gaps among the Soviet-trained and younger generations of specialists. There was a lack of modern technical skills and forward-looking vision among both old and new cadres, in his mind. The solution, for him, lay in learning from foreign expertise.

When we first started, we really lacked good experts and technologists. Those who studied during the Soviet times may have gotten good training, but their knowledge is really outdated at this point. I ended up recruiting a consultant from abroad. I was able to invite a consultant from Holland through an international organization that facilitates businesses.

Having trained a core group of employees, Bairam turned to the production process. He was not only concerned about bringing his production process up to modern standards, he was also concerned about halal compliance. Bairam relied on private halal certifiers to ascertain that the composition and process standards were halal-compliant. In regards to compositional standards, certification agencies prohibit the use of certain products relevant for confectionaries, such as pork-derived gelatin, thickeners, certain colorants, preservatives dissolved in alcohol, or any ingredients that could come from haram sources. Following the guidelines of the certification agency, Bairam changed several ingredients that he had used before, mostly related to gelatin and colorants. He replaced some of his former suppliers with others that were recommended to him as producers of halal-compliant products. Although he admitted that there was still room for doubt as to whether all of his suppliers were halal, he was happy to rely on the certifiers and their approval.

Interview, July 10, 2014. 
Bairam, like Aziza (to be discussed shortly), talks more about the integration of halal with business as such. Other entrepreneurs approach the question of how and why to become halal-compliant from a more personal perspective.

Taalim, the owner of a halal café in Bishkek in his late fifties, shared his experience while leaning back on a tapchan ${ }^{2}$ in his shady backyard. He was, by his own confession, into drinking and smoking less than a decade ago. Taalim had worked in Russia and enjoyed the carefree life of a man who had enough money to afford the lifestyle he enjoyed. Speaking of his shift to a pious lifestyle, he highlighted the story of a close relative: 'He had been into drinking, and lost his family and house as a result. He eventually died all alone with no family to support him. After his funeral, I asked myself whether I would be happy in the end of my life when I looked back.' At that point, Taalim started searching for ways to lead a meaningful life, and went on a dava'at trip to Bangladesh. He described it as a deeply transformative experience for him. 'I was there for forty days. There I quit smoking and drinking. We spent our time reciting the Quran and crying [yi menen ottu ubagybyz]. It turns out that crying eases the pain of your heart and clears your inner world [ichki duinong tazarat eken].' After his trip, Taalim decided to make his café more convivial for devout Muslims, and built separate prayer rooms for women and men and turned to halal certifiers to ensure that all the food at his café was fit for pious Muslims.

Nurlan, a young entrepreneur in his late twenties who co-owns and manages a family-run guest house in Osh, made a similar but more cogent connection between the moral individual and the social whole - in his words the immediate community as well as the nation. As we sat in a wooden garden house in the backyard of the guest house he ran, Nurlan shared his personal trajectory of piety and entrepreneurial aspirations in terms of improving national Kyrgyz character.

When I was a freshman in Bishkek, I already knew that there was something lacking in my life. I couldn't quite tell back then what exactly it was. Later, I ended up going to the US through the Work \& Travel Program. I actually was so lucky to travel with a guy who later became my close friend.... His name was Olaberdi, yes an Uzbek from Osh. He was already pretty religious back then. While there we worked and lived together. And what struck me most during my stay was that I met so many people from all over the world. And all those Christians from Spain or Christians from Latin American countries would tell me all kinds of stories about their homeland, but also about the Bible .... I realized I didn't 
know anything about my own religion back then, and I started spending more time at the library. ${ }^{3}$

For this young and eager entrepreneur, running a 'clean' guest house meant that alcoholic drinks and cigarettes were not allowed and that guests were offered halal food, but also that employees were respected and treated well was a way of contributing toward a better future for Kyrgyz society. Sharing his observations of the Kyrgyz people's national character, he noted:

You know, how our people [bizdikiler] tend to think that hanging out with friends and drinking is not only about having a good time, but causing mischief [jindilik salabyz]? I wanted to prove through my business, that we can also behave well, and that we can as Kyrgyz entrepreneurs do business well. When we started our guest house, people used to think that we basically opened a brothel. But overtime I think all of them came to realize that we're actually a clean business... they even call us 'halal guest house' although we don't call ourselves as such.

Echoing these sentiments, Aziza, a female daycare owner, also narrated a personal trajectory of spiritual awakening against the backdrop of weakening post-Soviet state institutions and the general moral degradation in everyday life. She indicated a lack of trust towards people who lack yiman (faith) or those who had not yet found 'the right Islam'. In her words, Islam, piety, and the tenets of halal had invigorated her desire to lead a 'clean' business that would also reinforce her sense of 'being a good Kyrgyz' as well as 'a good Muslim'. In these efforts, Islam, her religious teachers and private certifiers provided guidelines and resources for counteracting 'the haram' - things that were prohibited or corrosive in her society.

One instance that was commonly voiced among pious business owners was reconsideration of their relationship with state officials. Typically, local business owners are accustomed to solving any disputes with 'street-level bureaucrats' through bribes or krysha (protection, from Russian roof; see more in Ledeneva 1998). Although admitting that they still do give bribes when demanded, many of my respondents in this category said they have intentionally been avoiding corrupt practices. Aziza, for example admitted that she initially ran her daycare without proper registration, and subsequently had to

3 Interview, July 14, 2014. Stephan (2016) records additional cases of the formational influences of study on pious entrepreneurs. 
bribe some of the street-level bureaucrats who would come to check her gas and electricity meters. Since the building was registered as a 'private residence' and not a 'business', she paid lower utility rates and paid small bribes so that the officers would turn a blind eye. Checking the creases of her headscarf, she talked about her decision to come clean.

I eventually registered my daycare, and the whole building had to be officially documented as serving commercial purposes. As we were getting all of our paperwork done, one of the state workers came and asked for his usual amount. He very well knew we just didn't have all the documents ready yet, but still came asking. I couldn't help myself and started yelling - 'Do you know what's awaiting you in your next life? Bribes are haram!'

As she emotionally described her encounter, Aziza expressed her sense of pride that she now ran a registered business and did not need to hide from the bureaucrats. Often interweaving their personal trajectories into these narratives of the larger transformations that they have witnessed, entrepreneurs would suggest that private business - particularly ethical private business provides a unique means through which to socialize people properly. In these narratives, doubt and uncertainty maybe part and parcel of one's pious journey - at the same time however, understandings of what is properly 'halal' or 'Islamic' are intertwined with people's sense of ethnic and national belonging and a desire to lead a clean and uncorrupt life (see also Khalid 2007).

Are these experiences and deliberations among entrepreneurs in the halal economy discussed here unique to Kyrgyzstan or Central Asia? From the existing research on halal and haram elsewhere, we know that many similar processes are taking place in other contexts of the broader Eurasia. For example, Kalieszewska's (2020) work on Dagestani entrepreneurs shows how a subset of them in the halal economy have closely associated bribery with haram. Benussi similarly problematizes the question of halal certification in Tatarstan and discusses how members of the 'halal movement' have resisted the muftiate's authority (2018). In these and other studies of post-Soviet Islam, the question of authority and credibility in the religious realm is key. Most recently, Di Puppo and Schmoller (2020) discuss this question in the context of Russia and Turaeva $(2014,2019)$ addresses different networks through which religious authority and trust are cultivated among entrepreneurs and other pious Muslim networks broadly.

Entrepreneurs discussed in this section are a subset of actors in the valuation circuit referenced earlier. I adapt the concept of valuation circuits from 
Zelizer's 'economic circuits', which refer to a certain type of interaction that occurs when market actors face 'significant collective problems of trust in the absence of central authorities that could enforce agreements' (Zelizer 2010: 307) They are also likely to occur 'when the costs of defection and misbehavior for long-term collective welfare rise' (Zelizer 2010: 307). The relational approach that Zelizer promotes is attuned to exploring the shared meanings that market actors come to develop. From talking to the pious entrepreneurs, I found they were particularly vocal about the need to not only receive certification, but to actively earn it. For them, it was not only their visible market activities that needed to be halal; they were equally concerned about invisible actions monitored only by God. This discourse circulates among entrepreneurs, and is reinforced through Quran study groups, religious authorities and third-party halal certifiers. Drawing from these insights, I suggest that the halal valuation circuit involves distinctive social relations among entrepreneurs, certifiers and their transnational counterparts - it is in these circuits that economic activities are maintained through the collective action under uncertain or opaque rules. ${ }^{4}$

\section{Emergence of Halal Certifiers in Kyrgyzstan}

As the Islamic economy has grown larger and more lucrative since the early 20oos, the temptation to profit through disingenuous business practices has also grown. Local media outlets have sparked public debate by uncovering stories of allegedly fraudulent companies that claimed to produce halal or otherwise genuinely Islamic products. In June 2012, for example, the Abroi Company that specialized in producing halal sausages was accused of using pork and American-imported poultry in its production. ${ }^{5}$ In the fallout that ensued from this allegation, local communities of pious Muslims voiced their concerns that it was not easy for them to filter through the many companies that cluttered the market, some of which appeared to be duping their consumers. ${ }^{6}$ The matter was made worse by the fact that Abroi had been certified as a Halal producer by the muftiate in Kyrgyzstan. The halal certification branch under the muftiate that had issued the certificate was accused of 'turning religion into business'.

4 Other scholars have explored other similar 'circuits' (e.g. Anteby 2003, 2013; Knorr Cetina and Bruegger 2002; Morrill 1996; Velthuis 2003).

5 News source: http://kloop.kg/blog/2012/o6/o1/muftiya-obvinili-v-nezakonnoj-vy-dachehalal-sertifikatov/ - last accessed May 10, 2016.

6 News source: http://russian.eurasianet.org/node/6o455 - last accessed May 10, 2016. 
These types of episodes demonstrate the stakes for entrepreneurs of entering a moralized market niche. Those seeking a share of the demand for halal and Islamic goods face the potential loss of their reputation and profit for perceived malfeasance, even if the quality of their goods may not necessarily have been compromised. Not only potential rewards, but also clear risks present themselves to owners and managers who commit to running their business in line with religious or otherwise ethical norms and conventions. Similar risks confront certifiers as well, who offer their moral backing of companies.

The Halal Certification Agency (HCA) in Kyrgyzstan was established as a wing of the muftiate, officially known as the Spiritual Administration of Muslims in Kyrgyzstan. Although the muftiate's history goes back to the Stalinist policies of the Second World War (see more in Tasar 2017), initiatives such as halal certification emerged only in the early 20oos. The director of the HCA, Myktybek Arstanbek or Myktybek aji, ${ }^{7}$ initially worked under the muftiate with a small group of experts as a department of halal certification. Because of their work however, the muftiate found itself under attack by local media and prominent public figures, who cautioned against turning a revered theological institution into a place for profane commercial activities. The department of halal certification, like all certifiers, charged fees for its services, and critics saw that such fee-charging did not fit with the muftiate's broader mission.

Under this pressure, the certification department became an independent agency in 2013. Since HCA became self-sustaining, Myktybek aji has become a well-known lecturer on a wide array of issues related to Islam. A journalist by profession and already a widely-known figure prior to his current work, he has become well connected in the community of practicing Muslims. He delivers lectures at medressahs, mosque gatherings, and other public spaces.

The HCA still enjoys the official backing of the muftiate, giving it a distinct advantage over competing certification agencies. Despite its relatively recent inception, the HCA has outmaneuvered another third-party certification organization, the technical committee on halal standards, led by Kamchibek Omurzakov under the Islamic Center. Omurzakov claimed that the muftiate was using its religious authority to pursue business interests and to marginalize rival certification agencies. ${ }^{8}$ It was Omurzakov who took the lead in criticizing HCA for its complicity in the Abroi incident. His claims about HCA's monopolization of the market had some basis.

$7 \quad A j i$ is a title in Kyrgyz for someone who has completed pilgrimage to Mecca or haj. Interview conducted on June 24, 2014 .

8 News source: http://www.vb.kg/doc/200883_kamchybek_omyrzakov:_sozdannaia_myftiem_ standartizaciia_halal_nezakonna.html - last accessed, May 10, 2016. 
Although the Islamic Center actually began certifying private businesses first, it was quickly outcompeted by HCA. Indeed, the latter gained traction due to its official backing, and had issued certification to about 200 businesses in Kyrgyzstan between 2013 and 2015. These companies range from small and medium enterprises like meat stalls, bakeries, and daycares, to larger cafés, guest houses and food producers that work for both local and regional markets (especially Kazakhstan and Russia). At the time of my research, the Islamic Center was barely visible, and only a handful of entrepreneurs out of the eighty whom I interviewed knew about its existence. Hence, I focus on the HCA and their work as they establish their status as experts on issues related to halal.

The procedures of certification involve six different steps, as demonstrated in Figure 1. First, the HCA recruits companies - by way of advertising, but also by directly approaching company owners. Once an owner shows interest, the HCA conducts an initial audit of the company to determine its size and complexity, and agree with the owner on a fee for its certification services. Once the parties have agreed to proceed with certification, the HCA carries out one- or two week-trainings for the owners, managers and workers of the company.

At the end of these trainings, all trainees are required to pass written and oral exams. In the fourth stage, committee specialists attend the company and learn about their production process and working conditions. Depending on the company, this process takes one or two weeks, by the end of which the halal committee makes recommendations about various changes that the company must implement to be halal-compliant. Once the company completes these changes, the committee issues a certificate valid for one year. At the end of the year, renewal is possible with a shorter process and another payment.
1) Company
2) Trainings
recruitment
(1-2 weeks)
3) Written and oral exams

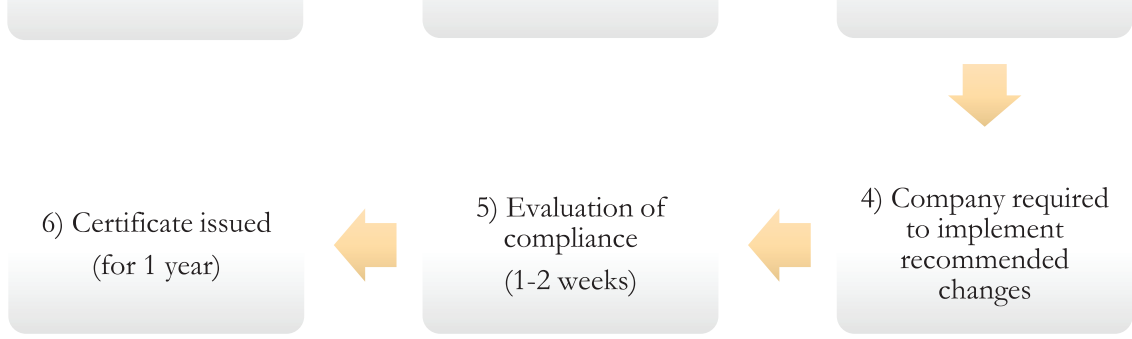

FIGURE 1 Process of certification 
The HCA issues a variety of recommendations, but they largely fall into three categories: the production process, working conditions, and relational aspects of running a business. First, recommendations on the production process normally start from specific rules for purification. The primary focus revolves around the ingredients or goods that are used in business. All of the components of production have to be halal, and haram ingredients are to be substituted by their licit equivalent. The agency recommended to Taalim, for example, that he eliminate the sale of alcoholic beverages and cigarettes in his café. Bairam was recommended to eliminate multiple ingredients in his pastry and cake production. Gelatin required special attention, and he shifted to using gelatin - not from Ukraine and Russia - but from Turkey, because gelatin produced there was made mostly from cattle or seaweed extracts.

Second, recommendations related to working conditions involved those that aimed to improve the sanitation of facilities and hygiene of workers. In pictures published on the HCA website, agency workers are depicted visiting various businesses in white coats and disposable gloves - so as to communicate the seriousness of their intentions to enforce hygiene and cleanliness.

Finally, recommendations on business relations encourage pious entrepreneurs to collaborate with other halal-certified businesses and partners. Through this attempt to tie the circuit members together, not just ideologically but also economically, the HCA has started publishing glossy monthly catalogues listing all of the certified companies' information. Besides these efforts to standardize guidelines and enforce them on businesses, local halal certifiers employ several tactics to reinforce the collective sense about the importance of 'halal' and to reinforce their authority in the market. In the sections that follow, I discuss the tactics through which the halal certifiers claim authority and distinguish themselves from religious authorities. In short, they emphasize their alleged technical knowledge and skills, localize halal and create binaries between halal and haram and, finally, rely on transnational networks of religious authority to boost their own credibility.

\section{Measuring the Unmeasurable?}

During my last interview with the director of the Halal Certification Agency in Kyrgyzstan in the summer of 2015, I asked whether he believed that all of the halal certified companies actually complied with the required standards. Perhaps accustomed to such critical questions, he was not taken aback, and affirmatively stated: 'Well, look... when a person with a driver's license gets into a car accident, we do not tend to blame those who issued the license, but 
the driver. It's the same thing here. I'm sure there are those who are cheating and using their halal certificates to brand themselves.' Later in the interview, Myktybek aji reflected upon the variation that exists among entrepreneurs who have been certified. Some, he noted, were pious and strictly followed the letter of Shariah law, but they were only a minority. Those who were profit-oriented, but still wanted to comply with technical halal standards were in the majority.

Myktybek aji's candid discussion indicates that despite an official rhetoric of working with measurable and technical halal standards, certifiers were quite reflexive about different interpretations and approaches to halal among entrepreneurs. In what follows, I discuss how the HCA's ability to recruit and enroll a growing numbers of entrepreneurs depends on more than their role as experts who impose standards and monitor compliance. HCA obtained its accreditation from the Halal Industry Association in neighboring Kazakhstan. These local Kyrgyzstani and Kazakhstani certifiers' appeal relies largely on their ability to be 'institutional entrepreneurs' (DiMaggio 1988, 1991; compare Bartley 2007) and to speak to the cognitive frameworks of entrepreneurs that generally fit the pious Muslim everywhere but are also specific to the local Muslim experience.

\section{Claiming Technical Knowledge}

The director of the Kazakhstani Halal Industry Association, Marat Sarsenbaev, in his interview in 2015 stated that the association's authority cannot be disputed by religious jurists or mosques who might also want to start issuing halal certificates:

Our organization was created ten years ago, and we have been registered with the Ministry of Justice. We are also accredited in the governmental system of certification. Thanks to our efforts there, our government standards involve halal standards as well, and we have the copyright to the standards related to production, storage and transportation of halal goods. ${ }^{9}$

As evident here, Marat Sarsenbaev draws a clear boundary with the religious authorities, and positions the Halal Industry Association as the legitimate governing body within the market. The association holds the 'copyright' because its standards have been incorporated into the government's standards, with

Source: http://kstnews.kz/news/market?node=20743 - last accessed May 5, 2016. 
which producers must inevitably comply. The association can indeed boast that its logo and reputation are widely recognized: beyond the six hundred companies it had certified by 2015 in Kazakhstan, producers from Russia, Belarus, and even Turkey had gone through its certification.

The Halal Certification Agency in Kyrgyzstan echoes their accreditors in Kazakhstan, and emphasizes the rational side of their halal standards. Myktybek Arstanbek asserted in one of his interviews to local journalists:

Halal standards are a technical expression of Shariah laws. Religious authorities issue fatwas, that for example pork is haram. Our role then is to find where pork and porcine residues can be present and to help producers eliminate such ingredients. It's not religious authorities' work to detect this. Let's take cake as another example. It can contain so many haram ingredients, including colorants, gelatin and alcohol. So for a cake to become halal, we need to work with producers, and the work may take up to half a year. We do our work considering that producers want to make sure that halal production is not going to be too costly for them, and that the taste of their cakes is not going to be compromised. It's hard work. And only after this meticulous work do we issue our certificate, which is good for one year. Throughout the year, we also make sure to visit certified producers, to make sure that they're complying with the standards. ${ }^{10}$

This rhetoric directly resonates with entrepreneurs as well.

Bairam, the confectionary shop owner, displayed his halal certificate in his office along with other diplomas and certificates from trainings he had attended locally and abroad. When I asked him why he went through halal certification, he answered:

I may not be very religious, but I do want my products to be actually halal. That's my ichki sezim, my inner feelings that drive my desire not just to stamp the label, but to actually comply. Halal is actually very much in line with food safety procedures... you probably know that food safety is big in Europe. So halal calls us to comply to religious tenets, but it's also just another term for products that are not harmful. ${ }^{11}$

For Bairam and many other entrepreneurs like him, halal production is as much about technologiya (technical production guidelines) as it is about their

10 Source: http://halal.kg/blogs/42 - last accessed June 5, 2016.

11 Interview conducted at his office, Osh, Kyrgyzstan. July 10, 2014. 
pious aspirations. The certification process confirms that they offer a product that is good and 'safe' for [Muslim] consumption.

Both certifiers and entrepreneurs often deployed a narrative that producing halal goods takes meticulous work following technical guidelines. Certifiers claim that they derive their knowledge from religiously-informed canons in the field. Their emphasis is on a technical and legal approach, which enhances their authority as experts, and reinforces the conventional view of halal certification as something static and measurable.

\section{Localizing Halal}

Grey areas inevitably arise in moral markets (Riaz and Chaudry 2004), particularly in cases where Shariah laws meet with local tastes and customs. In the Central Asian context, one telling example involves kymys (fermented mare's milk) traditional to the nomadic cultures of the Kyrgyz and Kazakh ethnic groups. The religious authorities in Kyrgyzstan have debated whether kymys should be considered haram for its minor alcoholic content, by which it could be considered intoxicating. After extensive debates, the muftiate issued a fikh that kymys was to be regarded as halal because its alleged health benefits outweigh its negligible alcoholic component, and because it is mostly consumed for restorative rather than recreational purposes. ${ }^{12}$ Furthermore, the fikh acknowledged that because kymys is seen as an authentic component of national heritage it could not be labeled haram, as this rhetoric would suggest that it was harmful and impure. The HCA in Kyrgyzstan heavily promotes these kinds of dual localization efforts that account for local foodways and heritage. Together with the HIA in Kazakhstan, they have collaborated with their Russian counterparts based in Tatarstan to institutionalize 'Eurasian halal standards'. Although these standards mostly resonate with Malaysian standards, they include some additional foods like horse meat and mare's milk.

Besides localizing halal standards, however, the HCA employs the rhetoric of 'protecting local markets'. These statements can be complex: the HCA promotes the idea that lucrative market niches should feed into the norms of

12 Similar deliberations have occupied religious authorities for centuries, not least in the sixteenth century coffee debate. According to Brown (2004), the coffee and coffee houses that quickly spread throughout Mecca, Cairo, Istanbul and other Middle Eastern cities in the sixteenth century, sparked a controversy leading to an assembly of legal experts. The jurists that gathered in 1511 in Mecca debated whether coffee should be classified as haram because it could be considered intoxicating like wine. Eventually, this line of argument was abandoned but coffee was still prohibited 'simply because it is vaguely harmful to one's wellbeing' (Brown 2014: 119). 
dominant ethnic, national and regional groups, thereby contributing to civic consciousness and public life. Halal standards, in particular, must meet the needs of 'traditional' national values. Additionally, technological rationale may be added to the statements. In an interview with Myktybek Arstanbek in the summer of 2015, for example, he added 'If you're a producer, you should source locally - then it's easier for us to trace the halal status of goods.'

\section{Creating Halal and Haram Binary}

Certifiers often emphasize that halal certification is also about cleansing and purifying your business practices. Although Myktybek aji considers pious entrepreneurs to constitute only a minority of those who have been certified, he delivers lectures to various Quran study groups, medressahs, and other religious associations on the need to practice Islam not only in word, but also in deed. He tells them economic outcomes such as material goods, money and success should only be secondary to the aspiration of paving the road to heaven.

The deliberate search and enactment for rules of the sacred by both entrepreneurs and certifiers that helps them construct a collective sense of demarcating moral space in an otherwise chaotic and unruly market. After going through certification, entrepreneurs expressed their pride in being clean, compliant with religious precepts, and making money through honorable business practices. It was evident that the process of going through halal certification and its encouraged deliberations over proper business conduct, spilled over to other activities that went far beyond a concern with ingredients and the technical aspect of production.

The narratives of pious entrepreneurs reveal collective representations that reflected the meaning-making at work and juxtapositions made to other non-halal market practices and spaces. These binaries (illustrated in Fig. 2) are reinforced through the narratives about what is good and what is bad, moral and corrupt; they shape the scripts that are perceived by entrepreneurs and their audiences as 'plausible' and the performances as 'authentic, sincere, or otherwise genuine' (Wherry 2012: 209). These shared meanings flow in the valuation circuit of the certification agency and certified entrepreneurs, generating internal collective beliefs and shaping ways in which these actors communicate their distinction to those outside of the circuit.

Certified entrepreneurs and the certifying agencies come to create 'shared understandings concerning the meaning of transactions within the circuit, including their moral valuation' (Zelizer 2010: 304). Once obtained, halal certificates communicate the authenticity and genuine intentions of the company, and hence are displayed on 'front stages'. Certificates are often laminated and 


\begin{tabular}{|c|c|}
\hline Halal-certified & Non-certified \\
\hline Compliant with religious precepts & $\begin{array}{l}\text { Compliance with religious and moral } \\
\text { values is questionable }\end{array}$ \\
\hline Bureaucratized and government-backed & Self-discretion is not legitimate \\
\hline Healthy & Potentially unhealthy \\
\hline Locally sourced, therefore easier to trace & Foreign, therefore more difficult to trace \\
\hline Nourishes spiritually & Corrupts spiritually \\
\hline $\begin{array}{l}\text { Produced through honorable business } \\
\text { practices }\end{array}$ & Produced through morally illicit practices \\
\hline Clean & Dirty \\
\hline
\end{tabular}

FIGURE 2 Binaries Produced through the Halal Certification Process ${ }^{13}$

displayed in storefronts or cafés, or framed and hanged in owners' offices to be seen by business partners. Thus, while halal certificates are technically only thin sheets of paper issued by the agency that ceremonially evaluates compliance to halal standards, they come to carry layers of meanings and sentiments for entrepreneurs.

\section{Relying on Transnational Network of Religious Authority}

When asked about their authority, officials of the Halal Certification Agency in Kyrgyzstan do not look just to religious authorities. They reference a broader network of halal certification centers - a complex system in which states are just as important as religious bodies, and in which near neighbors, regional trading networks, and major nodes in the global halal market all play a part (compare Granovetter 1983). HCA points first to the Halal Industry Association in Kazakhstan, from whom it received accreditation. HIA enjoys considerable political clout in Kazakhstan, and it reverberates across the region. According to Marat Sarsenbaev, the director of the HIA, support for the establishment of halal certification came directly from the chairman of the ruling party Nurotan (who also happens to be the nephew of Kazakhstan's president). Speaking enthusiastically of the administrative clout that his organization enjoys, Marat

13 Wherry (2012) presents the binaries that he sees being developed through the discourse of the sacred and profane in an art market. I borrow from him in developing this table. 


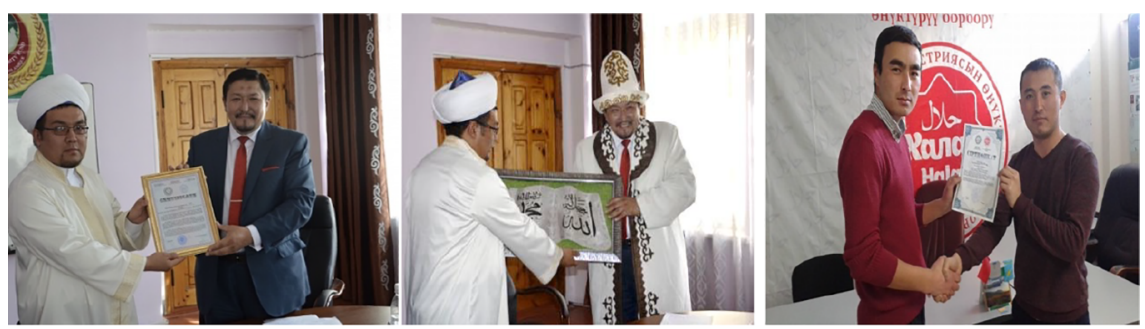

FIgURE 3 Valuation Circuits in PracticeFrom left to right, the head Muftiy in Kyrgyzstan receiving accreditation from Marat Sarsenbaev, who represents the Halal Industry Association in Kazakhstan; the head Muftiy reciprocates with a gift; the HCA in Kyrgyzstan grants a certificate to an entrepreneur. ${ }^{14}$

Sarsenbaev highlighted that Kazakhstan was among the first post-Soviet countries to include Malaysian halal standards into their gosstandart (government standards).

Officials of the Halal Industry Association in Kazakhstan are part of the Eurasian Union of Standardization and Halal Certification, which was established as an alliance between Kazakhstan, Russia and Belarus in 2012. As a result of this partnership with the religious authorities and independent halal certifiers in the post-Soviet region, HIA representatives signed an agreement for the mutual recognition of certificates issued by the respective certification agencies in these three countries. Under this agreement, halal products produced within any of the three countries are exempt from re-certification when exported to the other two countries. In addition to this partnership in the post-Soviet region, however, the HIA representatives point without fail to the International Halal Integrity Alliance (IHI Alliance) based in Kuala Lumpur, Malaysia, from whom they received accreditation. The IH I Alliance was formed as a result of a resolution passed at the World Halal Forum in May 2006, signed by over 30 countries interested in the development of the global halal industry chain. The IHI Alliance was a response to the 'absence of a credible reference center for information [that] has resulted in industries and consumers being bombarded with various interpretations of the meaning and application of halal, which often contradict each other.' ${ }^{15}$ The Malaysian IH I Alliance is connected to the Organization of Islamic Cooperation, which includes 58 member states.

In its turn, the growth of halal regulation in Malaysia has been driven primarily by the Malaysian state. As Fischer argues, Malaysian leaders aimed to turn the country into a global hub of halal production, trade and regulation,

14 Source: official website of HCA - http://halal.kg/galleries - last accessed May 10, 2016.

15 Source: http://www.ihialliance.org/home.php - last accessed, June 5, 2016. 

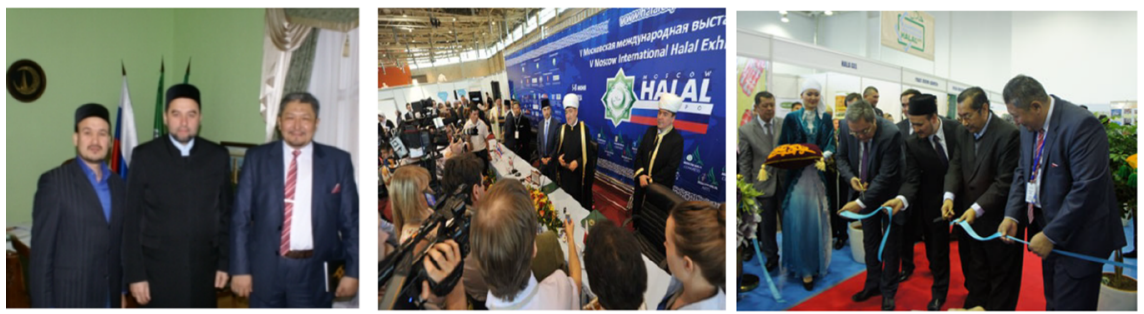

FIGURE 4 Transnational Valuation CircuitsFrom left to right, the Muftiy of Tatarstan, Ildus Faizov, center, holds a meeting with Marat Sarsenbaev, the president of the Halal Industry Association in Kazakhstan, far right; the Moscow Halal Expo in 2015; the Minister of Foreign Affairs in Malaysia, Dato' Ahmad Rasidi Hazizi officiating the Halal Expo in Kazakhstan in 2011 together with the representatives of the Ministry of Agriculture and Nurotan People's Democratic Party in Kazakhstan. ${ }^{16}$

and therefore 'intensified regulation and scientification of halal' (Fischer 2016: 40; see also Sloane 1999). Malaysia was able to export these standards abroad through world-wide halal forums, trade fairs, and the bureaucratization of procedures. As a result, Malaysia's MS 1500 standards (covering the production, preparation, handling and storage of halal food) and MS 2200 standards (covering consumer goods for cosmetic use and personal care) have become international benchmarks for halal certifiers (Fischer 2016).

\section{Conclusion}

The paper explored negotiations between pious entrepreneurs, certification agencies and their transnational accreditors. The distinction between halal and haram, Islamic and non-Islamic, applied to business activities through halal certification has introduced changes that are more than cosmetic alterations. ${ }^{17}$ As van Waarden \& van Dalen (2013: 208) point out, market actors, investors, entrepreneurs and consumers all have to engage in transactions 'as if' all halal goods and services are compliant with the stipulated standards. But this is not because the standards are meaningless. To the contrary, from the

16 Sources: 1) http://xn----7sbxcmhchjud6b.xn--piai/halal/?ID=19147 2) http://np-nasih.ru/ news/1202/3) http://www.kln.gov.my/web/kaz_astana/n2o11/-/asset_publisher/ME2g/blog/ kazakhstan-2nd-international-halal-expo-2011-19-21-october-2011-kazakhstan?redirect= \%2Fweb\%2Fkaz_astana\%2Fn2o11 - last accessed, June 5, 2016.

17 (Kuran 2010) claimed that adaptations of conventional financial products and procedures with only slight nominal changes were primarily done for the purposes of gaining their own brand of Islamic finance. 
perspective of economic sociology, business is changed because confronting the standards (and making them) involves a series of protracted meaning-making deliberations and new courses of action to be undertaken by both certifiers and to-be-certified entrepreneurs. A 'halal manner of doing business' becomes intertwined with various ethical codes that are seen as behavioral norms for entrepreneurs. These ethical codes include but are not limited to using better ingredients, treating employees well, not duping customers and choosing to not bribe government officials, some of which may be peculiar expressions of market actors moralizing markets in the context of post-Soviet economy.

Halal certification, although presented as a technical matter that will contribute to transparency in the market, is mostly anchored in the active work done in the valuation circuits of certification. In this respect, what can be certified as 'halal' conforms with collective sentiments around what is proper and improper business behavior - at least equally with workers, business partners, and community institutions, as with consumers - and these sentiments are aligned with defending ethnic and national Muslim identities and experiences.

Finally, the valuation circuit has an important transnational dimension. Kyrgyzstan's HCA gains authority from its accreditor in Kazakhstan, which is in turn accredited by the International Halal Integrity Alliance based in Kuala Lumpur, Malaysia. Even the Malaysian certifiers, however, look to the Malaysian state and to the Organization of Islamic Cooperation. In this circuit, each level of certifier depends on a higher level of accreditors to claim authority and credibility. This transnational circuit is a chain of moral authority through which halal is meant to become measurable, technical and translatable to market indicators such as price in national, regional and global economies. However, it cannot be implemented unless certifiers are able to relate and speak to different local sentiments and orientations of Islam.

\section{Acknowledgements}

I would like to thank Rano Turaeva and Michael Brose for organizing the 'Halal Economies in non-Muslim Countries' workshop at Indiana University Europe Gateway in 2019. I presented a draft of this paper there and benefitted from conversations with other workshop participants. We discussed the idea of putting together a special issue at the end of the event and Rano and Michael deserve special thanks for following through and seeing this collection of papers come to fruition. I would also like to thank two anonymous reviewers as well as Jennifer Cash for their time and suggestions as I worked on improving my initial draft. 


\section{References}

Anteby, Michel (2003). The 'moralities' of poaching: Manufacturing personal artifacts on the factory floor. Ethnography, 4(2): 217-239.

Anteby, Michel (2013). Manufacturing Morals: The Values of Silence in Business School Education. Chicago: University of Chicago Press.

Bartley, Tim (2007). Institutional emergence in an era of globalization: The rise of transnational private regulation of labor and environmental conditions. American Journal of Sociology, 113(2): 297-351.

Beckert, Jens (2013). Imagined futures: Fictional expectations in the economy. Theory \& Society, 42(March): 219-240.

Beckert, Jens and Christine Musselin (2013). Constructing Quality: The Classification of Goods in Markets. Oxford: Oxford University Press.

Benussi, Matteo (2018). Ethnic muslims and the 'halal movement' in Tatarstan. Anthropological Journal of European Cultures, 27(1): 88-93.

Bissenova, Alima (2017). The Return of Islam in post-Soviet Central Asia: Evaluating the past, looking to the future. In , Aitolkyn Kourmanova (ed.), Central Asia at 25: Looking Back, Moving Forward. A collection of essays from Central Asia, pp. 77-78. Washington, D.C.: The George Washington University.

Bogdanova, Elena (2013). Account of the past: Mechanisms of quality construction in the market for antiques. In , Jens MusselinBeckert and Christine (eds.), Constructing Quality: The Classification of Goods in Markets, pp. 153-173. Oxford: Oxford University Press.

Brown Daniel W. (2004). A New Introduction to Islam. Malden: Blackwell Publishers.

Dewally, Michaël and Louis Ederington (2006). Reputation, certification, warranties, and information as remedies for seller-buyer information asymmetries: Lessons from the online comic book market. The Journal of Business, 79(2): 693-729.

DiMaggio, Paul (1988). Interest and agency in institutional theory. In , L. Zucker (ed.), Institutional Patterns and Culture, pp. 3-22. Cambridge, MA: Ballinger Publishing Company.

DiMaggio, Paul and Walter Powell (1991). The iron cage revisited. In , Paul PowellDiMaggio and Walter (eds.), The New Institutionalism in Organizational Analysis, pp. 63-82. Chicago: University of Chicago Press.

DiPuppo, Lili and Jesko Schmoller (2020). Introduction: Studying Islam from below and interrogating divisions in contemporary Russia. Contemporary Islam, 14(February): 99-110.

Fischer, Johan (2016). Manufacturing halal in Malaysia. Contemporary Islam, 10: 35-52. Granovetter, Mark (1983). The strength of weak ties: A network theory revisited. Sociological Theory, 1: 201-233.

Imam, Patrick and Kangni Kpodar (2010). Islamic Banking: How Has It Diffused?. 
Kaliszewska, Iwona (2020). Halal landscapes of Dagestani entrepreneurs in Makhachkala. Ethnicities, 20(4)1-23.

Karpik, Lucien (2010). Valuing the Unique: The Economics of Singularities. Princeton: Princeton University Press.

Khalid, Adeeb (2007). Islam after Communism: Religion and Politics in Central Asia. Berkeley: University of California Press.

Knorr Cetina, Karin and Urs Bruegger (2002). Global microstructures: The virtual societies of financial markets. American Journal of Sociology, 107(4): 905-950.

Kuran, T. (2010). Islam and Mammon: The Economic Predicaments of Islamism. Princeton: Princeton University Press.

Ledeneva, Alena V. (1998). Russia's Economy of Favours: Blat, Networking, and Informal Exchange. Cambridge: Cambridge University Press.

Louw, Maria (2013). Even honey may become bitter when there is too much of it : Islam and the struggle for a balanced existence. Central Asian Survey 32(4): 514-526.

Louw, Maria Elisabeth (2007). Everyday Islam in Post-Soviet Central Asia. Abingdon and New York: Routledge.

Masters, William A. and Diakalia Sanogo (2002). Welfare gains from quality certification of infant foods: Results from a market experiment in Mali. American Journal of Agricultural Economics, 84(4): 974-989.

McBrien, Julia and Pelkmans Mathijs (2008). Turning Marx on his head. Missionaries, 'Extremists' and Archaic Secularists in post-Soviet Kyrgyzstan. Critique of Anthropology, 28(1): 87-103.

McBrien, Julia (2009). Mukadas's struggle: Veils and modernity in Kyrgyzstan. Journal of the Royal Anthropological Institute, 127-144.

McBrien, Julie (2008). The Fruit of Devotion: Islam and Modernity in Kyrgyzstan. Doctoral dissertation, Faculty of Philosophy, Martin-Luther-Universität Halle-Wittenberg.

Pelkmans, Mathijs (ed.) (2013). Ethnographies of Doubt: Faith and Uncertainty in Contemporary Societies. London: I.B. Tauris \& Co.

Potoski, Matthew and Aseem Prakash (2004). Regulatory convergence in nongovernmental regimes? Cross-national adoption of ISO 14001 certifications. The Journal of Politics, 66(3): 885-905.

Rasanayagam, Johan (2006). Healing with spirits and the formation of Muslim selfhood in post-Soviet Uzbekistan. Journal of the Royal Anthropological Institute, 12: 377-393.

Riaz, Milan and Muhammed Chaudry (2004). Halal Food Production. Milton Park: Taylor \& Francis.

Roy, Oliver (2004). Globalized Islam: The Search for a New Ummah. New York: Columbia University Press.

Sloane, Patricia (1999). Islam, Modernity, and Entrepreneurship among the Malays. New York: St. Martin's Press. 
Stephan, Manja (2016). Studying Islam abroad: Pious enterprises and educational aspirations of young Tajik Muslims. In , Pauline Jones Luong (ed.), Islam, Society and Politics and in Central Asia, pp. 263-289. Pittsburgh: University of Pittsburgh Press.

Tasar, Eren Murat (2017). Soviet and Muslim: The Institutionalization of Islam in Central Asia, 1943-1991. Oxford: Oxford University Press.

Turaeva, Rano (2014). Mobile entrepreneurs in post-Soviet Central Asia. Communist and Post-Communist Studies. 47(February): 105-114.

Turaeva, Rano (2019). Imagined mosque communities in Russia: Central Asian migrants in Moscow. Asian Ethnicity, 20(2): 131-147.

van Waarden, Frans van and Robin van Dalen (2011). Hallmarking halal, the market for halal certificates: Competitive private regulation. Jerusalem Papers in Regulation \& Governance, (33): 4-14.

van Waarden, Frans and Robin van Dalen (2013). Halal and the moral construction of quality: How religious norms turn a mass product into a singularity. In Beckert MusselinJens, and Christine (eds.), Constructing Quality: The Classification of Goods in Markets, pp. 197-222. Oxford: Oxford University Press.

Velthuis, Olav (2003). Symbolic meanings of prices: Constructing the value of contemporary art in Amsterdam and New York galleries. Theory and Society, 32(2): 181-215.

Wherry, Frederick (2012). Performance circuits in the marketplace. Politics \& Society, 4O(2): $203-221$.

Zelizer, Viviana (2010). Economic Lives: How Culture Shapes the Economy. Princeton: Princeton University Press. 